\title{
Beat Your Parodies into Swords, and Your Parodied Books into Spears: A New Paradigm for Parody in the Hebrew Bible
}

\author{
Will Kynes \\ University of Cambridge
}

\begin{abstract}
While previous works on parody in the Hebrew Bible have addressed the literary technique ad hoc in the service of the interpretation of specific texts, this article approaches the topic more broadly, attempting to understand the nature of the technique itself. Drawing on literary criticism, particularly the work of Linda Hutcheon, the commonly accepted definition of parody as a text which "ridicules" its "target" is questioned, and a broader definition of parody as "antithetical allusion," in which the earlier text may act as a "weapon" instead of a "target," and subversion and humor are only secondary features, is presented. This redefinition of the term grounds a new paradigm for parody that divides parody into four types: ridiculing, rejecting, respecting, and reaffirming. This paradigm is then applied to a series of exemplary parodies in the Hebrew Bible (Song 7:1-10, Psalm 29, Jonah, Job 7:17-18, Joel 4:10) that demonstrate the versatility of parody and the necessity of reading parodies in their wider context to determine their meaning.
\end{abstract}

\section{Keywords}

parody, Song of Songs, Psalm 29, Jonah, Job, Joel

"The word parody is currently the site of a rather onerous confusion." Gérard Genette made this observation in 1982, and, despite his best

1) G. Genette, Palimpsests: Literature in the Second Degree (trans. C. Newman and C. Doubinsky; Stages, 8; Lincoln: University of Nebraska Press, 1997), p. 24. This quotation is from the later English translation of his work. Similarly, Simon Dentith claims disputes over definition have "bedevilled" the discussion of parody. S. Dentith, Parody (New Critical Idiom; London: Routledge, 2000), p. 9. 
efforts, little has changed since. In the study of the Hebrew Bible in the past thirty years or so, interest in parody has grown, but clarity about the nature of this literary technique has not. Commentators have identified parodies in Jonah, ${ }^{2}$ Job, ${ }^{3} 2$ Samuel, ${ }^{4}$ Isaiah, ${ }^{5}$ and the Song of Songs, ${ }^{6}$ but all of these works have approached parody ad hoc, with their discussion of parody itself subordinate to their interpretation of a given passage. The closest one comes to a general study on parody in

2) E.g. J.E. Miles, "Laughing at the Bible: Jonah as Parody," JQR 65 (1975), pp. 16881; A.J. Band, "Swallowing Jonah: The Eclipse of Parody," Prooftexts 10 (1990), pp. 177-95; M. Orth, "Genre in Jonah: The Effects of Parody in the Book of Jonah," in W.W. Hallo, et al. (eds.), The Bible in the Light of Cuneiform Literature: Scripture in Context III (Ancient Near Eastern Texts and Studies, 8; Lewiston, NY: Edwin Mellen, 1990), pp. 257-81; A. Brenner, "Jonah's Poem out of and within its Context," in P.R. Davies and D.J.A. Clines (eds.), Among the Prophets: Language, Image and Structure in the Prophetic Writings (JSOTSup, 144; Sheffield: JSOT Press, 1993), pp. 18392.

3) In Job as a whole: K.J. Dell, The Book of Job as Sceptical Literature (BZAW, 197; Berlin: de Gruyter, 1991); B. Zuckerman, Job the Silent: A Study in Historical Counterpoint (Oxford: Oxford University Press, 1991); in the divine speeches: B. Sarrazin, "Du rire dans la Bible: la théophanie de Job comme parodie," RSR 76 (1988), pp. 39-56; in Job's allusion to Ps. 8:5 in Job 7:17-18: e.g. M. Fishbane, "The Book of Job and Inner-Biblical Discourse," in L.G. Perdue and W.C. Gilpin (eds.), The Voice From the Whirlwind (Nashville: Abingdon, 1992), pp. 86-98; S.E. Balentine, "'What are Human Beings, That You Make So Much of Them?': Divine Disclosure from the Whirlwind: 'Look at the Behemoth'," in T. Linafelt and T.K. Beal (eds.), God in the Fray (Minneapolis, MN: Fortress, 1998), pp. 259-78; C. Frevel, "Eine kleine Theologie der Menschenwürde': Ps 8 und seine Rezeption in Buch Ijob,” in F.-L. Hossfeld and L. Schwienhorst-Schönberger (eds.), Das Manna fällt auch heute noch: Beiträge zur Geschichte und Theologie des Alten, Ersten Testaments (HBS, 44; Freiburg: Herder, 2004), pp. 244-72.

4) H.S. Pyper, "The Enticement to Re-Read: Repetition as Parody in 2 Samuel," BI 1 (1993), pp. 153-66.

5) G.A. Yee, "The Anatomy of Biblical Parody: The Dirge Form in 2 Samuel 1 and Isaiah 14,” CBQ 50 (1988), pp. 565-86.

6) A. Brenner, "Come Back, Come Back the Shulammite' (Song of Songs 7:1-10): A Parody of the "Wasf Genre," in Y.T. Radday and A. Brenner (eds.), On Humour and the Comic in the Hebrew Bible (Sheffield: Sheffield Academic, 1990), pp. 251-75; J.W. Whedbee, "Paradox and Parody in the Song of Solomon: Towards a Comic Reading of the Most Sublime Song," in A. Brenner (ed.), A Feminist Companion to the Song of Songs (Feminist Companion to the Bible, 1; Sheffield: Sheffield Academic, 1993), pp. 266-78. 
Hebrew Bible criticism is Israel Davidson's Parody in Jewish Literature from 1907, which focuses on later Jewish works and actually denies the existence of parody in the Bible itself. ${ }^{7}$ The studies mentioned above counter Davidson's conclusion, and with interest in intertextuality continuing to grow, scholars are likely to uncover even more instances of parody in the Hebrew Bible.

Even so, recent developments in literary criticism, where parody's self-consciously literary nature, referred to as "metafiction," has made it a darling of postmodern theorists, suggest that assumptions commonly made about the literary technique are in need of revision. Parody is generally thought to employ humor to ridicule its literary "target," which I will refer to as its "precursor," ${ }^{\prime}$ and thus, the literary technique is most often discussed in the context of passages where this means and purpose are thought to be evident. However, this study will approach the topic more generally, addressing several texts in the Hebrew Bible, as well as a few outside of it, which will enable it to investigate the broader possibilities of parody. As examples spanning literary history from Jonah to James Joyce will suggest, the incongruity at the heart of parody need not indicate humor, and the antithesis between texts need not indicate antipathy. Instead, parodies may be serious, and they may even appeal respectfully to earlier texts as ideals standing in judgment over the situation the parody depicts. This broader understanding of parody will be of particular use to interpreters of the Hebrew Bible, where respect for earlier texts abounds, while humor is not prevalent, though likely more common than is generally thought.'

7) I. Davidson, Parody in Jewish Literature (Columbia University Oriental Studies, 2; New York: Columbia University Press, 1907), p. 1. Davidson's argument that parody plays a prominent role in Jewish literature may, in fact, point to a trajectory continuing from the Hebrew Bible itself. For a similar denial of parody in the Hebrew Bible, see D. Macdonald, (ed.), Parodies: An Anthology from Chaucer to Berbohm-and After (New York: Random House, 1960), p. 562.

8) Because the word "target" often used in the discussion of parody communicates the assumption of an antagonistic relation between the texts, I have chosen a more neutral term. Genette differentiates between the parody as a "hypertext" and the precursor as a "hypotext," but because "hypertext" has become part of the vocabulary of the internet, I have avoided that term as well (Genette, Palimpsests, p. 24).

9) See, for example, the articles in Y.T. Radday and A. Brenner, (eds.), On Humour and the Comic in the Hebrew Bible (JSOTSup, 92; Sheffield: Almond Press, 1990). 
Defining parody more broadly will add new questions to the interpretation of parodies recognized in the Hebrew Bible. For example, Johnny Miles, in a provocative article to which we will return in greater detail, argues that Jonah is a parody of the prophets, and as such it intends to attack Hebrew letters, and by extension, those returning Babylonian exiles who took them too seriously. ${ }^{10}$ My broader definition of parody will not disprove Miles's conclusion, but it will suggest that simply explaining the ways the author of Jonah parodies the prophets, which is all Miles really does, is not enough to support it because subversive ridicule is not the only intent ${ }^{11}$ a parody may have. ${ }^{12}$ Thus, by considering a wider range of texts and arguing for a broader definition of parody, I hope to direct interpreters back to the text with new questions in mind, questions which encourage a closer reading of the context of each passage. At the end of his book on parody, Simon Dentith warns that the mere definition of the word cannot be relied on to do the hermeneutical heavy lifting of determining the intended relationship between texts. He writes,

[T] he crucial questions remain: what cultural work is the parody effecting? On whose behalf is it working? With what wit and verve is the parody performed? None of these questions can be decided in advance, for all of them require an understanding of particular utterances in particular contexts. ${ }^{13}$

\footnotetext{
10) Miles, "Laughing," p. 170.

11) The use of the language of "intent" is intentional on my part since parody unavoidably forces the question of authorial intent on interpreters. Even Linda Hutcheon, who denies a "Hirschian view of the real author's meaning," must resort to the "encoded or inferred intention" embedded in the text to discuss parody (L. Hutcheon, $A$ Theory of Parody: The Teachings of Twentieth-Century Art Forms (New York: Methuen, 1985), pp. 88, 40).

12) Miles begins his article by stating, "Satire is the exposure by comedy of behavior which is standardized and, to that extent, foolish. Parody is that breed of satire in which the standardized behavior to be exposed is literary" (Miles, "Laughing," p. 168). However, as I will argue, standardized texts need not be regarded as foolish. In fact, they may act as authoritative standards, which parodies use to satirize the situations they depict.

13) Dentith, Parody, p. 188.
} 


\section{Defining Parody}

The first crucial question is how exactly to define parody. The Oxford English Dictionary [OED] gives the following definition:

A composition in prose or verse in which the characteristic turns of thought and phrase in an author or class of authors are imitated in such a way as to make them appear ridiculous, especially by applying them to ludicrously inappropriate subjects, an imitation of a work more or less closely modelled on the original, but so turned as to produce a ridiculous effect. ${ }^{14}$

The OED has captured the common usage of the word well; some idea of ridicule often appears in attempts to define the literary technique. However, ridicule is an overly vague concept. For example, in her work on parody, Linda Hutcheon sometimes equates ridicule with humor and other times seems to identify it with disparagement or denunciation. ${ }^{15}$ By disentangling the possible meanings of ridicule, we can better discern what exactly is involved in the common understanding of parody.

First, though, to be an imitation, a parody must respond to a previous text or group of texts, as the OED suggests. ${ }^{16}$ The "texts" that parodies imitate have been understood broadly; one theorist claims that parodies target "utterances," which he defines as "speech acts as discourse in a context," ${ }^{17}$ while another discusses parodies of works of art ranging from oil paintings to opera. ${ }^{18}$ Parodies are distinguished based either on the quantity of texts parodied or the means used to parody

\footnotetext{
14) $O E D$, s.v. 'parody.'

15) For an observation of the former confusion, see M.A. Rose, Parody: Ancient, Modern, and Post-modern (Literature, Culture, Theory, 5; Cambridge: Cambridge University Press, 1995), p. 239 n. 146. For an example of the latter, see Hutcheon, Parody, p. 58.

16) T. Shlonsky, "Literary Parody: Remarks on Its Method and Function," in F. Jost (ed.), Proceedings of the IVth Congress of the International Comparative Literature Association, Friebourg 1984 (The Hague: Mouton, 1966), pp. 797-801; Hutcheon, Parody, p. 43.

17) G.S. Morson, "Parody, History and Metaparody," in G.S. Morson and C. Emmerson (eds.), Rethinking Bakhtin: Extensions and Challenges (Evanston: Northwestern University Press, 1989), pp. 63, 72.

18) Hutcheon, Parody.
} 
them. In the former case, parodies may either be "general," imitating a body of texts, such as a genre or the works of one author, or "specific," addressing a particular text. ${ }^{19}$ As to the means used, "material" parody alludes to a text's content, while "formal" parody emulates the style of a text, author, or genre. ${ }^{20}$ Parodies may employ more than one of these techniques at once, and often do. In the examples discussed later, we will see all four types of parody in the Hebrew Bible, though it must be acknowledged that, because we do not have access to every text known to the biblical authors, any general parody could actually be a specific one directed to a text unknown to us. In some cases, ancient Near Eastern texts can lessen our ignorance by at least indicating the types of genres that the biblical authors may have been familiar with.

Second, in order for ridicule to occur, there must be some difference between the original and the parody's imitation. As the OED says, the original must be "so turned as to produce a ridiculous effect." In a sense, every imitation is different from the original, if only because it places the original words in a new context, but unlike other allusions to earlier texts, the emphasis in parody is particularly on this difference. Thus, Hutcheon defines parody as "repetition with critical distance which marks difference rather than similarity." ${ }^{21}$ This emphasis on the difference between the two texts sets parody apart from allusion, which highlights their correspondence. ${ }^{22}$

Third, when the OED claims that a parody intends to make the original "appear ridiculous," it suggests that the parody aims to subvert its precursor. Thus, Gary Morson asserts, "A parodic utterance is one of open disagreement. The second utterance represents the first in order to discredit it, and so introduces a 'semantic direction' which subverts that of the original." 23 Similarly, while discussing parody in Job,

19) Dentith, Parody, p. 7.

20) G. Highet, The Anatomy of Satire (Princeton, NJ: Princeton University, 1962), pp. 69-72.

21) Hutcheon, Parody, p. 6. Similarly, S. Johnson, A Dictionary of the English Language (London: J. Johnson, etc, 9th edn., 1806); S. Stewart, Nonsense: Aspects of Intertextuality in Folklore and Literature (Baltimore, MD: Johns Hopkins University Press, 1978), p. 185.

22) Hutcheon, Parody, pp. 34, 43.

23) Morson, "Parody," p. 66. Similarly, Highet, Satire, p. 68. 
Katharine Dell claims parody's "keynote" is "the way in which it uses existing material in order to show up the weaknesses of that material, on the level of form as well as content." 24

Fourth, ridicule also implies humor. The OED claims parody makes features of the original work appear ridiculous "especially by applying them to ludicrously inappropriate subjects." Humor is mentioned as a defining characteristic in many definitions of parody. For example, Margaret Rose insists on comic effect as a quality of parody because without it she believes the definition would not serve a "useful, distinct purpose." 25 She claims that without humor, parody is little more than imitation, reduced to a "very general concept of 'difference."”26 Several biblical scholars agree with her. David Marcus asserts that the "comic element is essential to parody," Gale Yee claims humor is parody's "chief result," and Miles defines parody as a type of literary humor. ${ }^{27}$

With these clarifications in mind, we can sum up the common definition of parody as a literary technique which:

1. evokes or indicates another utterance [allusion],

2. is, in some respect, antithetical to its target [antithesis],

3. is clearly intended by its author to subvert the authority of the original [subversion],

4. involves humor [humor]. ${ }^{28}$

24) Dell, Sceptical, p. 152. Similarly, Zuckerman, Job, p. 44.

25) M.A. Rose, Parody//Meta-Fiction: An Analysis of Parody as a Critical Mirror to the Writing and Reception of Fiction (London: Croom Helm, 1979), p. 20. See also Rose, Parody, pp. 20-36. Beate Müller, whose work has been influential in the German discussion of Parodie, similarly claims that intertextual comedy is an obligatory aspect of parody. The title of her book even glosses parody as "komische Intertextualität." B. Müller, Komische Intertextualität: die literarische Parodie (Horizonte, 16; Trier: Wissenschaftlicher Verlag Trier, 1994), p. 224.

26) Rose, Parody, p. 240 n. 147.

27) D. Marcus, From Balaam to Jonah: Anti-Prophetic Satire in the Hebrew Bible (BJS, 301; Atlanta, Ga: Scholars Press, 1995), p. 20; Yee, "Biblical Parody," p. 568; Miles, "Laughing," p. 168.

28) The first three criteria are adapted from Morson, "Parody," p. 67. He rejects the fourth (69), but I have included it because it is often claimed to be essential to the definition. 
Hutcheon's work on parody draws the final two aspects of this definition into question. Instead of restricting our definition of parody to texts which humorously subvert their precursors, Hutcheon argues that we should recognize that parody has "a wide range of forms and intents," which stretch from "witty ridicule to the playfully ludic to the seriously respectful." ${ }^{29}$ The etymology and diachronic development of the term considered along with a range of literary examples and semantic distinctions between parody and related terms demonstrate the versatility of the literary technique.

First, in the Greek word $\pi \alpha \rho \omega \delta$ í $\alpha$, from which the English term

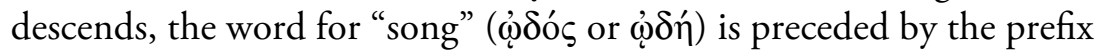
$\pi \alpha \rho \alpha$, which may mean "counter" or "against," resulting in the common understanding of parody as a "counter-song," which ridicules the text it parodies. However, the prefix has a second possible meaning, "beside," which would then suggest accord instead of contrast and may even communicate respect for the original. ${ }^{30}$ Considering the classical usage of the word $\pi \alpha \rho \omega \delta i \alpha$, Fred Householder concludes that the word did not normally imply ridicule or denunciation of the passage or author parodied. In fact, he suggests that the ridiculing connotations of the English word "parody" may have misled commentators on Aristophanes, the great classical Greek parodist, to assume that his parody of Euripides's plays in Frogs, indicated that he regarded Euripides as an inferior poet, whose work deserved to be mocked, when, in fact, he was likely a great admirer. ${ }^{31}$

29) L. Hutcheon, "The Politics of Postmodern Parody," in H.F. Plett (ed.), Intertextuality (Research in Text Theory, 15; Berlin: de Gruyter, 1991), pp. 225-26.

30) Hutcheon, Parody, p. 32. F.J. Lelièvre claims the two meanings of the Greek prefix were combined as in other compounds with $\pi \alpha \rho \alpha$. F.J. Lelièvre, "The Basis of Ancient Parody," Greece and Rome: Series 21 (1954), pp. 66-81 (66).

31) F.W. Householder, Jr., "ПАР $\Omega \Delta \mathrm{IA}, "$ CP 39 (1944), pp. 1-9 (6). See the qualified agreement in Lelièvre, "Ancient Parody," p. 75 and the extended argument for this view in R.E. Wycherley, “Aristophanes and Euripides,” Greece and Rome 15 (1946), pp. 98-107. In fact, in Frogs, line 71, Aristophanes has Dionysus explain his quest for Euripides as a longing for a tragedian who is dexios ("clever" or "talented"), a trait Aristophanes elsewhere claims for himself (Clouds, lines 521-48). Also by pitting Euripides against Aeschylus for the throne of tragedy, Aristophanes implicitly makes a positive judgment of both. See Aristophanes, Frogs and Other Plays; translated by David Barrett; revised translation with an introduction and notes by Shomit Dutta (Penguin 
Second, avoiding the etymological fallacy by examining the diachronic development of the concept, Hutcheon claims the current generally held definition of parody "is still tainted with eighteenth-century notions of wit and ridicule." 32 According to Hutcheon, though ridicule and wit were not always considered essential to parody's definition, the eighteenth century's admiration of these qualities and commingling of parody and satire (e.g. the works of Alexander Pope and Jonathan Swift) have had a continuing dominating influence on attempts to define the term, so that "from then on, parody had to be funny and pejorative." 33 There were some exceptions to this general trend. For example, in 1806, Samuel Johnson still gave parody a neutral definition: "a kind of writing, in which the words of an author or his thoughts are taken, and by a slight change adapted to some new purpose." ${ }^{34}$ Even so, Henryk Markiewicz's investigation into the development of the definition of the term in the modern period supports Hutcheon's contention. According to Markiewicz, already in the seventeenth century, the common modern definition of parody had appeared, but other definitions can be found, such as "the recast of a serious work for satirical purposes, directed, however, not against the model but aimed at ridiculing contemporary customs or politics" or "the changing of a serious work into another serious work." 35 However, by the nineteenth century, parody had become most closely connected to the ridicule of its precursor. ${ }^{36}$

Classics, London: Penguin, 2007), pp. xxiv-xxv, 130. For the majority view that Householder questions, see, e.g. K.J. Dover, Aristophanic Comedy (London: Batsford, 1972), p. 73.

32) Hutcheon, "Politics," pp. 225-26.

33) Hutcheon, Parody, p. 51. See H.D. Weinbrot, "Parody as Imitation in the 18th Century," American Notes and Queries 2 (1964), pp. 131-34. Similarly, Rose, Parody, p. 54.

34) Johnson, A Dictionary of the English Language.

35) H. Markiewicz, "On the Definitions of Literary Parody," in vol. 2 of R. Jakobson (ed.), To Honor Roman Jakobson (Janua Linguarum. Series Maior, 31-33; The Hague: Mouton, 1967), p. 1265.

36) Markiewicz, "Parody," p. 1269. Correspondingly, Davidson observes that Jewish parody was not intended "to pull down the ancient models from their high pedestals. ... It did not spring from the desire to disparage, but rather from the wish to 
Third, examples of what Hutcheon calls "respectful" or "reverential" 37 parody from across literary history embody the second meaning of the Greek term both before and after witty ridicule came to dominate the discussion of parody. The earliest examples are mock epics, which applied Homer's epic style to trivial subjects, such as the classical Batrachomyomachia, or Battle of the Frogs and Mice. "The mock epic did not mock the epic," Hutcheon declares. Instead, she claims, "it satirized the pretensions of the contemporary as set against the ideal norms implied by the parodied text or set of conventions." ${ }^{38}$ Similarly, the parodies of Shakespeare in Punch magazine did not mock his work, but only used his speeches as a vehicle for their satire, ${ }^{39}$ and T.S. Eliot often parodied earlier works not to criticize them but to hold them up as standards by which to judge contemporary moral degeneracy. ${ }^{40}$

Fourth, Hutcheon attempts to carefully parse out the differences between parody and two words which contribute to what she calls the "taxonomic muddle" surrounding the term: irony and satire..$^{41}$ Both of these concepts often feature in parodies and as a result the meanings of all three are often conflated. The overlap between parody and irony has produced the assumption that parody must be humorous, while the overlap with satire has contributed to the presupposition of subversion. These are both cases of the fallacy of weak analogy. In the crossover between these literary techniques, they share some quality, and this leads interpreters to apply other qualities of the one technique to the other.

In the former case, both irony and parody work through highlighting incongruity. This incongruity is also the essence of humor, ${ }^{42}$ and

emulate. In fact, no Hebrew parody written before the middle of the eighteenth century ever aimed at ridiculing the text of the original" (Davidson, Parody, p. xviii).

37) E.g. Hutcheon, Parody, pp. 58, 60, 62.

38) Hutcheon, Parody, p. 44. Similarly, Householder, "ПАР $\Omega \Delta \mathrm{IA}$," p. 3; Lelièvre, “Ancient Parody," p. 71; Markiewicz, "Parody," p. 1268; Dentith, Parody, p. 11.

39) Hutcheon, Parody, p. 58.

40) Hutcheon, Parody, p. 57. For example, Eliot's parody of Edmund Spenser's benign bridal song "Prothalamion" in The Waste Land "measures the sordidness of 1920s' sexual relations" and "draws on the authority of the parodied text to establish its own evaluative stance" (Dentith, Parody, pp. 17-18).

41) Hutcheon, Parody, p. 52.

42) Highet, Satire, p. 67. Similarly, Rose, Parody, p. 34; Müller, Komische Intertextualität, 
in many cases both irony and parody capitalize on it for exactly this purpose. ${ }^{43}$ However, when parody uses irony to signal the incongruity between the original work and the text which incorporates it, Hutcheon claims, "The pleasure of parody's irony comes not from humor in particular but from the degree of engagement of the reader in the intertextual 'bouncing' ... between complicity and distance." ${ }^{44}$ In fact, Sander Gilman identifies the confusion of incongruity and humor as a common fallacy in the definition of parody. ${ }^{45}$ Recognizing this, several critics deny that humor is an essential element of parody ${ }^{46}$ Instead, humor is a secondary result of parody's emphasis on difference.

Whereas parody often uses irony, satire often employs parody as a vehicle for its assault, which has led many theorists to label parody a form of satire. ${ }^{47}$ However, Hutcheon differentiates the two on the basis

p. 224. There are indications of this incongruity theory of humor in Cicero's De Oratore, where he writes, "The most common kind of joke is that in which we expect one thing and another is said; here our own disappointed expectation makes us laugh" (quoted in S. Critchley, On Humour [London: Routledge, 2002], p. 1). As a theory, it can be traced to Francis Hutcheson's Reflections Upon Laughter (1750), though it was elaborated by Immanuel Kant, Arthur Schopenhauer, and Søren Kierkegaard. There are two other prominent theories: one that argues that laughter is motivated by a feeling of superiority over others (supported by Plato, Aristotle, Quintillian, and Thomas Hobbes), and the other that laughter is the release of pent-up nervous energy (Herbert Spencer, Sigmund Freud). See Critchley, Humour, pp. 2-3.

43) For example, classical parodies often aimed "to exploit the humorous potentialities of incongruity by combining high-flown tragic diction and allusions to well-known tragic situations with vulgarity or trivial domestic predicaments" (Dover, Aristophanic Comedy, p. 73).

44) Hutcheon, Parody, p. 32. Similarly, J.A. Dane, "Parody and Satire: A Theoretical Model," Genre 13 (1980), pp. 145-59 (146).

45) S.L. Gilman, The Parodic Sermon in European Perspective: Aspects of Liturgical Parody from the Middle Ages to the Twentieth Century (Beiträge zur Literatur des XV. bis XVIII. Jahrhunderts, 6; Wiesbaden: Steiner, 1974), pp. 1-2.

46) E.g. U. Weisstein, "Parody, Travesty, and Burlesque: Imitations with a Vengeance," in F. Jost (ed.), Proceedings of the IVth Congress of the International Comparative Literature Association, Friebourg 1984 (The Hague: Mouton, 1966), p. 803; Hutcheon, Parody, p. 20; Morson, "Parody," p. 69; Dentith, Parody, p. 37. In her work on Job, Dell also argues that humor is not a necessary feature of parody (Dell, Sceptical, pp. 148-53).

47) Hutcheon, Parody, p. 43. Gilbert Highet even claims, "Parody ... is one of the chief shapes satire assumes" (Highet, Satire, p. 69). 
of their targets: parody's target is “intramural," another text, while satire addresses an "extramural" target, which is a concern outside the text, whether social or moral. ${ }^{48}$ In his treatment of Jonah, Miles makes this same distinction. ${ }^{49}$ However, he goes on to claim that though the proximate target of a parody is a text, it may have an ultimate target in "real life," which is those who take that text seriously. ${ }^{50}$ This conflation of the intra- and extramural aims of the text confuses parody and satire and has "muddled" the definition of parody. ${ }^{51}$ Because satire often uses parody, and parody commonly has satiric aims, this confusion is understandable. However, if we distinguish between the literary target of a parody and the social or moral target of its satirical attack, it becomes clear that just because one text parodies an earlier one does not necessarily mean that it is attempting to subvert that text; the assault may be directed elsewhere. ${ }^{52}$ In fact, in one text, parody and satire can go in opposite directions, with the parody directed at the earlier text but appealing to it respectfully so that the satire may be directed at the

48) Hutcheon, Parody, p. 43. Similarly, Shlonsky, "Parody," p. 798; Dane, "Parody," p. 145.

49) Miles, "Laughing," p. 168. Similarly, Band, "Swallowing Jonah,” p. 192; Orth, "Genre in Jonah," p. 261. Due to this distinction, Michael Dick incorrectly identifies as parodies the prophetic polemics against the making of cult images, in which the process of making an idol and then worshipping it is mocked (e.g. Isa 44:9-22). Though he hints at the possibility that the prophets may have been aware of the Mesoptamian $m \bar{i} s p \hat{\imath}$ ritual $(41-42,43)$, he does not demonstrate that they were alluding to an earlier work, either a text or an utterance. See M.B. Dick, "Prophetic Parodies of Making the Cult Image," in M.B. Dick (ed.), Born in Heaven, Made on Earth: The Making of the Cult Image in the Ancient Near East (Winona Lake, IN: Eisenbrauns, 1999), pp. 1-53; similarly W.M.W. Roth, "For Life, He Appeals to Death (Wis 13:18): A Study of Old Testament Idol Parodies," CBQ37 (1975), pp. 21-47. Because of this, Isa 44:9-20 and texts like it are better classified as "satires," e.g. P.D. Hanson, Isaiah 40-66 (Interpretation, Louisville, KY: John Knox Press, 1995), p. 89; B.S. Childs, Isaiah (OTL, Louiville, KY: Westminster John Knox Press, 2001), p. 343. 50) Miles, "Laughing," pp. 168, 170. Similarly, Yee, "Biblical Parody," pp. 567-68; Morson, "Parody," p. 72.

51) Hutcheon, Parody, p. 104.

52) Hutcheon, Parody, p. 50. Dentith similarly claims that "the polemic can work both ways: towards the imitated text or towards the 'world'. Thus it is certainly true, even taking familiar literary examples, that parody does not have to have a polemical relation to the texts that are 'quoted'" (Dentith, Parody, p. 17). 
later. ${ }^{53}$ In this way, as J.A. Yunck observes, parody may use its precursor as a "weapon" instead of as a "target." 54

Because this understanding turns the common understanding of parody upside down by reversing the direction of its attack, a couple of examples may help to clarify how this type of parody works. First, when describing James Joyce's Ulysses, Northrop Frye is impressed by "the elaborate way that the story and characters [of Ulysses] are parodied by being set against archetypal heroic patterns, notably the one provided by the Odyssey." 55 For example, Molly, Joyce's modern version of Penelope, Odysseus's faithful wife, is anything but chaste as she waits for her husband. ${ }^{56}$ However, this antithetical allusion to the Odyssey is not intended to criticize the ideal behavior the epic depicts. Instead, the difference between the two texts exposes the moral failing of the contemporary world Joyce describes. Thus, in Frye's understanding, Joyce's parody of the Odyssey has become a weapon directed at the world depicted in Ulysses and not at the Odyssey at all. Thus, it would be more accurate to say that the world described in Ulysses is satirized through the way it parodies the Odyssey.

In addition to referring to larger aspects, such as character and plot, this reverse type of parody may also appeal to a line or two from an earlier text. Juvenal, the Roman satirist, incorporates altered phrases from high poetry into his satires to juxtapose the noble world of literature or legend with the depraved morals of the world as he portrays it. ${ }^{57}$ For example, in lines 99-100 of Juvenal's second satire, he attacks the emperor Otho for being effeminate. He writes: ille tenet speculum, pathici gestamen Othonis, / Actoris Aurunci spolium ("Another holds a mirror, the weapon wielded by the pathic Otho, / 'the spoil of Auruncan

\footnotetext{
53) As Hutcheon observes, "Parody ... invokes a self-conscious critical distancing of the Other which can be used as one of the rhetorical mechanisms to signal the reader to seek immanent, if indirect, ideal standards whose deviation is to be satirically condemned in the work" (Hutcheon, Parody, p. 78, emphasis original. See also, p. 62). 54) J.A. Yunck, "The Two Faces of Parody," Iowa English Yearbook 8 (1963), pp. 29-37. Cited in Hutcheon, Parody, p. 52.

55) N. Frye, Anatomy of Criticism: Four Essays (Princeton, NJ: Princeton University Press, 1957), p. 313. Emphasis added.

56) Hutcheon, Parody, p. 5. Similarly, Dentith, Parody, p. 91.

57) F.J. Lelièvre, "Parody in Juvenal and T.S. Eliot," CP 53 (1958), pp. 22-26.
} 
Actor""58). The first line parodies Aeneid 3.286, where Virgil describes the shield "wielded by the great Abas" (magni gestamen Abantis), and the second line comes directly from Aeneid 12.94. This parody creates "a moral contrast between the heroic figures of the Aeneid and the degeneracy of Otho and those like him." Thus, it serves as "a dramatic reminder of higher values." ${ }^{59}$

\section{A New Paradigm for Parody}

Hutcheon has identified strains of parody that the strong influence of the eighteenth century has obscured. These texts share the emphasis on difference with the more commonly acknowledged parodies, but they do not express ridicule, either by showing respect for their precursors or by not being particularly funny, or both. Faced with this lack of fit between the definition of parody and texts which have been recognized as parodies, we have two options.

First, we may maintain the more narrow commonly accepted definition of parody, and, since these other parodies do not fit that definition, label them something else. Genette takes this sort of approach when he proposes a "taxonomic and terminological reform," in which parody is restricted to the playful transformation of a text, one cell in a table like this:

\begin{tabular}{|c|c|c|c|}
\hline relation $\longrightarrow$ & playful & satirical & serious \\
\hline transformation & PARODY & TRAVESTY & TRANSPOSITION \\
\hline imitation & PASTICHE & CARICATURE & FORGERY \\
\hline
\end{tabular}

58) English translation from L. Evans, The Satires of Juvenal, Persius, Sulpicia, and Lucilius (New York: Harper \& Brothers, 1860), p. 12.

59) Lelièvre, "Parody," p. 24. Maurice Bowra identifies this same technique in the work of T.S. Eliot. See M. Bowra, "T.S. Eliot, The Waste Land," The Creative Experiment (London: Macmillan, 1949), pp. 181-82. 
Genette divides these various relationships between texts into narrow categories and gives each a name. The dotted line in Genette's table indicates the impossibility of drawing a clear boundary between the three moods. Tellingly, he claims that serious transformations of texts have "never been considered in themselves," and thus do not have a formal name, forcing him to invent one: "transposition." " Also, in restricting parody to playful transformation, he denies it any "aggressive or mocking intention." ${ }^{61}$ Despite his attempt at terminological reform, Genette acknowledges that new terms rarely catch on, so even he has little hope of this solution being successful. ${ }^{62}$ Additionally, in this case, these other types of texts have been referred to as parodies for so long that a semantic redistribution like this is likely only to contribute to the confusion. In fact, the meaning of many of the terms in Genette's table are themselves debated, and works on parody often devote large sections to differentiating parody from each of them.

A second possible response is to revise the definition of parody. To encompass the many types of parody, Dentith defines the term broadly and inclusively: "Parody includes any cultural practice which provides a relatively polemical allusive imitation of another cultural production or practice." ${ }^{63} \mathrm{He}$ prefers to see parody "as a range in the spectrum of possible intertextual relations" because tight formal definitions overlook significant usage. ${ }^{64}$

Dentith's broader approach agrees better with Hutcheon's discussion of parody, which has the effect of moving the third and fourth aspects of the narrower definition, subversion and humor, from the essential to the secondary. ${ }^{65}$ One might also attempt to move the second,

60) Genette, Palimpsests, p. 28.

61) Genette, Palimpsests, p. 27.

62) Genette, Palimpsests, p. 26.

63) Dentith, Parody, pp. 6, 9.

64) Dentith, Parody, p. 37.

65) Though I am discussing parody as a literary technique and not only as a genre, by distinguishing between "essential" and "secondary" features of parody, I am taking an approach similar to that of K.S. Whetter in his work on genre in Medieval Romance. $\mathrm{He}$ argues that "genres are recognized and defined by the presence of a number of features; for all of the mutability and variety of these features and the genres they create, some features are merely commonplace and some are essential: it is the essential 
which declares that parody must be in some sense antithetical to its target. There would be some historical precedent for this, as Householder observes that the Greek word $\pi \alpha \rho \omega \delta$ í $\alpha$ was sometimes used in this way, especially in the context of rhetoric. ${ }^{66}$ However, if this were done, nothing would distinguish parody from allusion or imitation. The term would be broadened to the point where it loses its meaning. However, if we retain the two qualities of allusion and antithetical reference, we describe a distinctive literary technique, an evocation of an earlier text which emphasizes difference instead of correspondence, or more simply, an antithetical allusion. The common characterization of this antithesis as "ridicule" seems to have imported subversion and humor into our understanding of parody, but neither is necessitated by the basic literary technique. Because of the incongruence between these evocations and their precursors, they are often humorous, but they need not be. The mood of some texts can be serious, or, in fact, anything in between. ${ }^{67}$ Because this antithesis between texts is an effective vehicle

features which define a genre" (K.S. Whetter, Understanding Genre and Medieval Romance [Hampshire: Cambridge University Press, 2008], p. 32). This distinction also accords well with John Swales's prototypical definition of genres. Attempting to mediate between a definitional approach and a family resemblance approach, Swales suggests that the most typical members of a category are prototypes against which other members are judged. Thus a robin is "birdier" than an ostrich since it, to use my terms, expresses the "essential" qualities of a bird as well as the prominent "secondary" qualities (e.g. it flies, perches in trees, and sings), while an ostrich has less of those "secondary" qualities. See J.M. Swales, Genre Analysis: English in Academic and Research Settings (The Cambridge Applied Linguistics Series, Cambridge: Cambridge University Press, 1990), pp. 49-52. Thus, though parodies that employ subversion and humor may be considered the prototypical types of parody in contemporary opinion, texts without these qualities, which still express the essential qualities of allusion and antithesis, may still be considered parodies.

66) Householder, "ПАР $\Omega \Delta \mathrm{IA}, "$ p. 7.

67) Dell points out that the distinction between what is funny and what is serious is actually "very subjective," especially when the interpreter is separated from the original culture surrounding the text by a great deal of time (Dell, Sceptical, p. 152). Athalya Brenner claims humor is bi-polar in nature, with its semantic range extending from laughter and the comic on one extreme to contempt, insult, and ridicule on the other. See A. Brenner, "On the Semantic Field of Humour, Laughter and the Comic in the Old Testament," in Y.T. Radday and A. Brenner (eds.), On Humour and the Comic in the Hebrew Bible (JSOTSup, 92; Sheffield: The Almond Press, 1990), p. 40. Because 
for satire, parodies may be intended to ridicule their precursors by subverting their authority, but this is not necessarily the case. They may instead respectfully use the precursor as a weapon to attack some aspect of the world depicted in the parodying text. Thus, the authority may lie with either the parody or its precursor. ${ }^{68}$ These possibilities are depicted in the following chart, which clarifies the confusion created by Hutcheon's ambiguous use of the word "ridicule"

\begin{tabular}{|c|c|c|}
\hline mood & humorous & serious \\
\hline parody & I & II \\
(precursor as & Ridiculing & Rejecting \\
"target") & 1. imitation & 1. imitation \\
& 2. antithesis & 2. antithesis \\
& 3. subversion & 3. subversion \\
4. humor & III & IV \\
(precursor & Respecting & Reaffirming \\
"weapon") & 1. imitation & 1. imitation \\
& 2. antithesis & 2. antithesis \\
\hline
\end{tabular}

of the subjectivity of recognizing humor and the fact that humor on Brenner's latter pole may be nearly indistinguishable from serious disparagement, I would prefer to consider incongruity and not the humor which often results from it as one of the defining characteristics of parody.

68) It is possible, as Morson suggests, for the reader not to know which voice to agree with (he calls this "metaparody") but this does not mean that the two texts share authority. Morson, "Parody," 68.

69) This chart also addresses a weakness in Rose's argument that parody must be comic. She claims that though some post-modern theorists have overcome the modern and late-modern false disjunction of parody between comic and "meta-fictional" modes, they are liable to make the mistake of "restricting parody to only the meta-fictional and the comic," thus obscuring the fact that "parody can be used in a variety of different ways and for both meta-fictional and non-meta-fictional comic purposes" (Rose, Par$o d y$, p. 278, emphasis original). This variety of different uses, which Rose acknowledges, raises the question of the necessity of a comic purpose. Why is the meta-fictional aspect secondary but the comic essential? Her argument that, without humor, parody would not serve a "useful, distinct purpose" (see page 4) seems to be a straw man when one considers the purpose to which difference is put in some of Hutcheon's examples. 
Like Genette, I have used a dotted line to represent the impossibility of drawing a clear boundary between the two moods. Unlike Genette's table, I have removed "satirical" as a mood because the word better describes a text's function. Also, my table only addresses parody, so there is no row for "imitation"; all these categories emphasize difference. Instead, I have differentiated between whether the parody or its precursor is given authority over the other in the parody.

All of these types of parody display its two essential criteria: imitation and antithetical emphasis, but they differ on how many of the secondary criteria (humor and subversion) they employ. The names I have given each type of parody highlight the different nuances of the attitudes these parodies take to their precursors. The types of parodies in quadrants one and two in the upper row both subvert their precursors by asserting their authority over them and treating them as targets, but the parodies in the first quadrant also employ humor, so they are "ridiculing," while those in quadrant two are merely "rejecting." The common understanding of parody outlined above would be the "ridiculing" type in quadrant one. The "rejecting" parody in quadrant two would be the serious parody for which Genette invented the label "transposition" because the usual definition of parody did not include it.

Because the parodies in quadrants three and four in the lower row appeal to their precursors as an authority instead of attempting to subvert them, using them as weapons instead of targets, they do not fit in the general understanding of parody. Even so, Dentith claims that these types of parodies must also be included in the word's definition. ${ }^{70}$ Though both types treat their precursors with respect, the parodies in quadrant three in some cases parody their precursors primarily to create a humorous effect, as is the case in some mock epics, so I have labeled them merely "respecting" parodies. Because humor is not the aim of the parodies in quadrant four, they are more likely to reaffirm the authority of the precursor to satirize a situation in the contemporary world, and thus to act as "reaffirming" parodies, though "respecting" parodies may also have this same function. "Reaffirming" parodies are the farthest from the common definition of parody since they demonstrate only the essential features and neither of the secondary ones.

70) Dentith, Parody, p. 9. 
Either we adapt the definition of parody to include them, as Hutcheon and Dentith suggest, or we must invent a separate category for them..$^{71}$ Because many of these texts are already referred to as parodies, and, as Hutcheon demonstrates, the broader definition seems to agree better with the etymology and historical use of the word, revising the definition seems the preferable option. A clearer definition of parody will enable more accurate evaluation of the contributions of parody in the Hebrew Bible. For example, in some cases, interpreters seem predisposed to see humor and subversion in cases of antithetical allusion because these features are assumed to be part of the definition of parody. If they are only aspects of some parodies and not others, then this conclusion must be justified based on the context of the passage in question.

\section{Parody in the Hebrew Bible}

Having described this new paradigm for parody, to demonstrate its hermeneutical value I will now apply it to a number of parodies which interpreters have identified in the Hebrew Bible. I would like to focus on the interpretation of parodies instead of their identification, so I will restrict myself to texts which commentators have previously identified as parodies. $^{72}$

71) In biblical studies, Benjamin Sommer seems to take the latter approach when he refers to some antithetical allusions to earlier texts as "reversals," e.g. B.D. Sommer, A Prophet Reads Scripture: Allusion in Isaiah 40-66 (Stanford, CA: Stanford University Press, 1998), pp. 36-46. According to this broader definition of parody, if these allusions emphasize difference instead of correspondence, they could be considered parodies. Of one of these "reversals" he says, "One might have thought that this sort of allusion signifies Deutero-Isaiah's rejection of his predecessor. On the contrary, he uses the rhetoric of reversal to underscore how apt Jeremiah's warnings were" (41). Thus, he describes what I have called a "reaffirming" parody.

72) The identification of parodies is complicated by their intrinsically indirect nature and the necessity of recognizing the precursor in order for the parody to be understood as such. Parody shares these difficulties with allusion generally but then compounds them by emphasizing the difference instead of the correspondence between the two texts. Morson provides some helpful diagnostic signs of parody (e.g. exaggeration, understatement, punning, incongruity, and change of context), though his analysis 


\section{Ridiculing Parody: Song of Songs 7:1-10}

Despite the fact that "ridiculing" parody combines humor and subversion, the commonly accepted features of parody, few of the parodies in the Hebrew Bible that have received significant discussion actually fit into this category. Athalya Brenner provides one possible example. She suggests that Song 7:1-10 $0^{73}$ is a humorous parody of the wasf, or descriptive love poem, a genre evident in several ancient Near Eastern texts. ${ }^{74}$ As such, it would be a general parody of a genre employing the formal parody of its style. Song of Songs also includes two other wasfs earlier in the book $(4: 1-7 ; 5: 10-16)$, which are apparently true to the genre, so it could be considered a specific parody of one of those, though there are no references to their content of the type used in material parodies to indicate that the author had these particular texts in mind. Brenner's argument hinges on the imagery in vv. 2-6 (NRSV):

works on the faulty assumption that a parody must subvert its precursor. See Morson, "Parody," p. 70. For more indicators, see Rose, Parody, pp. 37-38.

73) I follow the Hebrew numbering here and in subsequent biblical references.

74) Michael Fox provides several ancient examples of this genre, for example, this one from Papyrus Chester Beatty I:

The beginning of the Sayings of the Great Entertainer

One alone is (my) sister, having no peer: more gracious than all other women.

Behold her, like Sothis rising at the beginning of a good year:

shining, precious, white of skin, lovely of eyes when gazing.

Sweet her lips ‘when' speaking: she has no excess of words.

Long of neck, white of breast, her hair true lapis lazuli.

Her arms surpass gold, her fingers are like lotuses.

Full (?) (her) derrière, narrow (?) (her) waist, her thighs carry on her beauties

M.V. Fox, The Song of Songs and the Ancient Egyptian Love Songs (Madison: The University of Wisconsin Press, 1985), p. 52. 
2 How graceful are your feet in sandals, O queenly maiden! Your rounded thighs are like jewels, the work of a master hand.

3 Your navel is a rounded bowl that never lacks mixed wine. Your belly is a heap of wheat, encircled with lilies.

4 Your two breasts are like two fawns, twins of a gazelle.

5 Your neck is like an ivory tower. Your eyes are pools in Heshbon, by the gate of Bath-rabbim. Your nose is like a tower of Lebanon, overlooking Damascus.

6 Your head crowns you like Carmel, and your flowing locks are like purple; a king is held captive in the tresses.

Brenner claims that instead of undertaking the normal description of his beloved's beauty from head to toe, the poet here, from toe to head, draws a comic picture of a "mixed bag" with fat belly, jumpy breasts, long neck, turbid eyes, and outsized nose. ${ }^{75}$ In this way, the parody of the wasf in Song 7:1-10 serves satirically as a "protest against conventional, idolized, idealized images of love and of the female love object." 76

J. William Whedbee finds Brenner's reading so compelling that, following her lead, he argues for further parodies in the book, including the wasf describing the man in 5:10-16. ${ }^{77}$ With his rods of gold for arms, a body of polished ivory, and alabaster columns for legs, his appearance may be "choice as the cedars" of Lebanon (v. 15) but, as Whedbee remarks, he stands "somewhat awkwardly as a gargantuan, immobile, distant figure. ${ }^{78}$ Based on this collection of parodies in the book, Whedbee concludes that the parody aims to "subvert the conventional male dominance in patriarchal and royal society." 79

Brenner and Whedbee may be right about these parodies, we cannot know for sure, but the ambiguity of the Song's imagery and our cultural distance from the time of its composition leave significant room for doubt. For example, responding to Brenner's interpretation of the imagery in ch. 7, Cheryl Exum claims the comparison of the beloved's

\footnotetext{
75) Brenner, "Come Back," pp. 260, 267.

76) Brenner, "Come Back," p. 272.

77) Whedbee also sees a parody in the hyperbolic description of Solomon's royal procession (3:7-11) when compared to a similar description of the lowly Shulamite (6:89), Whedbee, "Paradox," pp. 270-71.

78) Whedbee, "Paradox," p. 274.

79) Whedbee, "Paradox," p. 274.
} 
belly to a heap of wheat in v. 3 is intended to communicate its softness instead of its size. ${ }^{80}$ Other commentators have suggested that the metaphor is intended to express the shape and skin color of the woman's stomach, ${ }^{81}$ her fertility, ${ }^{82}$ and even all of the above. ${ }^{83}$ Given the ambiguity of the metaphors, Brenner's strongest argument for the parody is the fact that the poet reverses the direction of description of the normal wasf, going from foot to head, but she herself acknowledges that this may have to do with the fact that the poem begins with the woman dancing, when we would expect attention directed to her feet. ${ }^{84}$ In addition, due to our cultural and chronological distance from the poem's original setting, any judgment of its tone is subjective. ${ }^{85} \mathrm{After}$ all, beauty is in the eye of the beholder. Even if Brenner has interpreted the metaphors correctly, how do we know that fat bellies and large noses were not prized as the pinnacle of pulchritude in ancient Israel ${ }^{86}$ If the wasf in Song of Songs 7 is not funny, if its imagery describes the woman in a positive manner just like the others, then it is not significantly different than the earlier examples of the wasf in the book, and, without this antithesis, it is not a parody.

\section{Rejecting Parody: Psalm 29}

In the second quadrant in the paradigm is "rejecting" parody, which is serious and attempts to subvert its precursor. Psalm 29 is a possible

80) J.C. Exum, Song of Songs: A Commentary (OTL, Louisville, KY: Westminster John Knox, 2005), p. 234. Similarly, Fox asserts, "This simile does not mean that she had a potbelly", Fox, Song of Songs, p. 159, emphasis original.

81) F. Delitzsch, Commentary on the Song of Songs and Ecclesiastes (trans. M.G. Easton; Clark's Foreign Theological Library. 4th series, 54; Edinburgh: T. \& T. Clark, 1891), p. 125.

82) R.E. Murphy, The Song of Songs: A Commentary on the Book of Canticles or the Song of Songs (Hermeneia, Minneapolis: Fortress Press, 1990), p. 186. Similarly, R.S. Hess, Song of Songs (Baker Commentary on the Old Testament Wisdom and Psalms, Grand Rapids, MI: Baker Academic, 2005), p. 214.

83) D. Bergant, The Song of Songs (Berit Olam; Collegeville, MN: Liturgical Press, 2001), p. 84.

84) Brenner, "Come Back," p. 260. See T. Longman, Song of Songs (NICOT; Grand Rapids, MI: William B. Eerdmans, 2001), p. 189.

85) Hess, Song of Songs, p. 215 n. 32.

86) See the discussion in Fox, Song of Songs, p. 159. 
example of this type. Similarities between Psalm 29 and the Canaanite theology of Hadad-Baal have long been noted. ${ }^{87}$ By comparing the psalm with one praising the palace of Baal from the Ugaritic Baal cycle, it becomes evident that these theological similarities are joined by stylistic ones:

Psalm 29:

1 A Psalm of David. Ascribe to the LORD, O heavenly beings, ascribe to the LORD glory and strength.

2 Ascribe to the LORD the glory of his name; worship the LORD in holy splendor.

3 The voice of the LORD is over the waters; the God of glory thunders, the LORD, over mighty waters.

4 The voice of the LORD is powerful; the voice of the LORD is full of majesty.

5 The voice of the LORD breaks the cedars; the LORD breaks the cedars of Lebanon.

6 He makes Lebanon skip like a calf, and Sirion like a young wild ox.

7 The voice of the LORD flashes forth flames of fire.

8 The voice of the LORD shakes the wilderness; the LORD shakes the wilderness of Kadesh.
CAT 1.4 VII lines 29-42:

29-30 Baa[l] gave forth his holy voice. Baal repeated the is[sue of (?)] his $[\mathrm{li}(?)] \mathrm{ps}$,

31-35 His ho[ly (?)] voice covered (?) the earth,

[At his] voice ... the mountains trembled.

The ancient [mountains?] leapt [up?], The high places of the ear[th] tottered.

35-37 The enemies of Baal took to the woods, The haters of Hadd to the mountainsides.

37-38 And Mightiest Baal spoke:

38-39 "O enemies of Hadd, why do you tremble?

Why tremble, you who wield a weapon against the Warrior?"

After the "Address to the Divine Council" common to Canaanite hymns, the psalm, like the Baal hymn, describes the power of the Lord's voice through its violent effects in the natural world, before concluding with the Lord enthroned. The repetitive parallelism and mixed meter of the psalm may also reflect Canaanite style. ${ }^{89}$ Due to these similarities, some

87) Though this insight is often traced back to H.L. Ginsberg's article in 1936, T.H. Gaster suggested it a few years earlier. See H.L. Ginsberg, "The Ugarit Texts," Orientalia 5 [1936], pp. 129-31; T.H. Gaster, "The Earliest Known Miracle-Play?," Folklore 44 (1933), pp. 379-90 (382 n. 13).

88) English translation from M.S. Smith and W.T. Pitard, The Ugaritic Baal Cycle. Volume II. Introduction with Text, Translation and Commentary of KTU/CAT 1.3-1.4 (VTSup, 114; Leiden: Brill, 2009), pp. 84-85.

89) F.M. Cross, "Notes on a Canaanite Psalm in the Old Testament," BASOR 117 (1950), pp. 19-21 (19-20). On this basis, Hans-Joachim Kraus claims, "Without doubt we have in Psalm 29 archaic meters that clearly stand out from other OT 
have suggested that this psalm is an ancient hymn to Baal slightly modified for liturgical use in Israel. ${ }^{90}$ As such, it would reflect the presence of a "more primitive folk-religion" in Israel. ${ }^{91}$ But Leland Ryken argues that the psalm is a parody of Canaanite poetry, which, by substituting YHWH for Baal, "makes the point that what the pagans serve as Baal is really God. Jehovah, not Baal, is the one who deserves to be enthroned and praised in song." 92 Though this psalm may be a specific parody of a Canaanite hymn lost to history, its reflection of Canaanite style suggests that it is at least a general parody of Canaanite praise. ${ }^{93}$ Its antithetical treatment of this praise for the purpose of subverting it in favor of praise of the God of Israel indicates that it may rightly be termed a parody even though the psalm's serious subject matter makes humorous intent unlikely.

But how can we know this was the psalm's original intent? Could it not simply have been the adoption of Canaanite hymnic style without a polemical purpose? In my understanding of parody, it differs from allusion by accentuating difference instead of correspondence. The main difference between this hymn and its purported Canaanite precursors

psalmic poetry. It is correct procedure to recognize the undeniable relation of Psalm 29 to ancient Canaanite texts." H.-J. Kraus, Psalms: A Continental Commentary (trans. H.C. Oswald; Minneapolis: Fortress Press, 1993), vol. 1, pp. 345-46.

90) F.M. Cross, Canaanite Myth and Hebrew Epic: Essays in the History of the Religion of Israel (Cambridge, MA: Harvard University Press, 1973), pp. 151-52. See also M.J. Dahood, Psalms (AB, 16-17A; Garden City, N.Y: Doubleday, 1966), vol. 1, pp. 174-80.

91) T.H. Gaster, "Psalm 29," JQR 37 (1946), pp. 55-65 (65).

${ }^{92)}$ L. Ryken, Words of Delight: A Literary Introduction to the Bible (Grand Rapids, MI: Baker Book House, 1987), pp. 253-54. Peter Craigie similarly claims that the psalm mocks belief in Baal by praising God for powers that were attributed to Baal. See P.C. Craigie, Psalms 1-50 (WBC, 19; Nashville: Nelson, 2004), pp. 246, 249. Additionally, John Goldingay calls the psalm a "polemical statement over against Canaanite faith." J. Goldingay, Psalms (Baker Commentary on the Old Testament Wisdom and Psalms, Grand Rapids, MI: Baker Academic, 2006), vol. 1, p. 414.

93) Some, such as B. Margulis, deny that there is an actual Canaanite hymn underlying Psalm 29, but even he affirms, "That the author of Ps 29 has gone to school with the Canaanite bards ... is undeniable." B. Margulis, "The Canaanite Origin of Ps 29 Reconsidered," Bib 51 (1970), pp. 332-48 (346). Similarly, P.C. Craigie, "Psalm XXIX in the Hebrew Poetic Tradition," VT 22 (1972), pp. 143-51 (144). 
is the replacement of the names of Canaanite deities with the name of Israel's God, which is underscored by appearing eighteen times in a mere eleven verses! Hans-Joachim Kraus expresses this point as follows:

... we surely cannot fail to recognize the polemically antithetic components that very pointedly militate against worshipping Canaanite deities. Psalm 29 gains circulation as a Yahweh hymn in a world characterized by Baal worship. Thereby the claim of the creator, Yahweh, on the world of heaven and earth becomes evident. Yahweh appears. Yahweh's כבוד radiates forth. Yahweh's voice resounds. Yahweh makes heaven and earth quake. To him all powers must bow in homage, and him must they serve. ${ }^{94}$

\section{Respecting Parody: Jonah}

As we move to the third quadrant in the paradigm, we consider "respecting" parodies, so named because, though they employ humor, they do not attempt to subvert the texts they parody. Jonah may serve as an example. In Jonah, everything is turned upside down - prophets disobey, wicked Gentiles repent, and fish eat people - and thus, unsurprisingly, Jonah is often interpreted as a parody. ${ }^{95}$ However, interpreters who read the book in this way usually consider it to be both humorous and subversive toward the prophetic tradition, which would suggest that it is better characterized as a "ridiculing" parody. ${ }^{96}$ For example, Miles claims the book takes aim at Hebrew scripture and those who took it too seriously..$^{97}$ Miles identifies in Jonah the parodic manipulation of

\footnotetext{
94) Kraus, Psalms, vol. 1, p. 351.

95) According to Orth, this interpretation goes back to Thomas Paine (Orth, "Genre in Jonah," p. 258).

96) E.g. Miles, "Laughing"; Band, "Swallowing Jonah"; Orth, "Genre in Jonah." Several other scholars have labeled Jonah satire instead, e.g. J.S. Ackerman, "Satire and Symbolism in the Song of Jonah," in B. Halpern and J.D. Levenson (eds.), Traditions in Transformation (Winona Lake: Eisenbrauns, 1981), pp. 213-46; J.C. Holbert, “'Deliverance Belongs to Yahweh!': Satire in the Book of Jonah," JSOT 21 (1981), pp. 59-81; Marcus, Balaam to Jonah, pp. 93-159. This dispute over the genre of the book reflects the confusion of the two genres, as the commentators who consider the book a parody often speak of its "satirical intent" while those who read it as a satire often rely heavily on its use of parody to make their case.

97) Miles, "Laughing," p. 170. Similarly, Orth, “Genre in Jonah,” pp. 272-73.
} 
five scenes in the stereotyped narrative of the prophetic career, which would make it a general parody that, by alluding to the content of its generic precursor, employs material parody: ${ }^{98}$

\begin{tabular}{|l|l|l|}
\hline Narrative Element & Expected Behavior & Jonah \\
\hline Call to prophecy & $\begin{array}{l}\text { Reluctance expressed in } \\
\text { anguished eloquence (e.g. } \\
\text { Exod. 4:10; Judg. 6:15; } \\
\text { Jer. 1:6) }\end{array}$ & $\begin{array}{l}\text { Sails in the opposite } \\
\text { direction, silence }\end{array}$ \\
\hline Sign (storm at sea) & $\begin{array}{l}\text { Awed obedience (e.g. } \\
\text { Judg. 6:22; Isa. 6:8) }\end{array}$ & Sleeping, resignation \\
\hline $\begin{array}{l}\text { Psalm of thanksgiving } \\
\text { after rescue }\end{array}$ & $\begin{array}{l}\text { Water imagery used } \\
\text { metaphorically (e.g. Ps. } \\
130)\end{array}$ & $\begin{array}{l}\text { Water imagery used } \\
\text { literally }\end{array}$ \\
\hline $\begin{array}{l}\text { Rejection of prophet by } \\
\text { king }\end{array}$ & $\begin{array}{l}\text { Prophetic word is lengthy, } \\
\text { impassioned, and ignored } \\
\text { (e.g. Exod. 5:1-11; 1 Kgs } \\
22: 13-28)\end{array}$ & $\begin{array}{l}\text { One sentence, } \\
\text { unprecedented penitence }\end{array}$ \\
\hline Prophet's response & $\begin{array}{l}\text { Despair because message } \\
\text { not heeded (Num 11:10- } \\
15 ; 1 \text { Kgs 19:4; Jer 20:7- } \\
8)\end{array}$ & $\begin{array}{l}\text { Despair because message } \\
\text { is heeded }\end{array}$ \\
\hline
\end{tabular}

Miles's third element, the psalm of thanksgiving, is more a parody of psalmic language than prophetic narrative, but it contributes to the general parodic tone he attempts to deomonstrate in the book. ${ }^{99}$ Adele Berlin, on the other hand, denies that Jonah is a parody at all, and

98) Miles, "Laughing". Orth follows Miles, and discusses several more prophetic topoi that are parodied in the book (Orth, "Genre in Jonah").

99) He refers to the psalm as a parody of the "biblical genre" of "the psalm of thanksgiving for rescue from the pit" (Miles, "Laughing," p. 173, emphasis original). For fuller treatments of the parody of the psalms in Jonah's prayer, see Ackerman, "Satire"; Brenner, "Jonah's Poem." This parody of psalmic language need not be subversive. Instead, like the mock epics, which also applied high rhetoric to inappropriate subjects, it may express respect for the language itself, while using the unexpected, and in this case, overly literal, subject matter for humorous purposes. This humor would then be directed more at Jonah's inability to use the language appropriately than at the psalms themselves. 
points out that even if it were, its inclusion in the canon demonstrates that it was a failed one misunderstood by some of its earliest readers. ${ }^{100}$

If Jonah's parody is respectful, however, we can reconcile these two contrasting positions. André and Pierre-Emmanuel LaCocque propose that, far from mocking the prophetic tradition with which the parody interacts, the book builds on it, as the universalism of Third Isaiah informs the book's theology and there is "no theoretical opposition to Ezekiel or Jeremiah." 101 According to the LaCocques, the prophetic tradition to which the narrative refers both generically (in the exaggeration and reversal of prophetic type-scenes) and specifically (in allusions to particular passages) actually serves as a standard by which the book criticizes both the Israelites who refuse to repent (unlike the Ninevites, who do) and the reader who, like Jonah, resists God's election. ${ }^{102}$ Though Marcus calls Jonah an "anti-prophetic satire," he concludes that the principal message of the book is the satire of the prophet himself as "Jonah is satirized for behavior thought to be unbecoming to a prophet." 103 This actually supports the LaCocques' reading, for it is only by upholding a prophetic standard that such a judgment may be made. Like Joyce's parody in Ulysses of the heroic patterns in the Odyssey, when Jonah responds to God's call by running in the opposite direction, he, and not the prophets who obeyed as they should, is the butt of the joke. Jonah would then be a respecting parody which, though humorous, respectfully uses the prophetic texts it parodies as a standard by which to satirize the unrepentance and disobedience of its readers. This is how Jesus uses the story in Luke 11:32, and it also accords with the fact that it is read in the synagogue as part of the ritual of repentance on the Day of Atonement. ${ }^{104}$ This interpretation would resolve Berlin's question

100) A. Berlin, "A Rejoinder to John A. Miles, Jr. with Some Observations on the Nature of Prophecy," JQR 66 (1976), pp. 227-35. Similarly, some argue the canonizers may not have recognized the parody and satire in the book, e.g. Band, "Swallowing Jonah," p. 194; Marcus, Balaam to Jonah, p. 169.

101) A. LaCocque and P.-E. LaCocque, Jonah: A Psycho-Religious Approach to the Prophet (Columbia, SC: University of South Carolina Press, 1990), pp. 18-20, 22.

102) LaCocque and LaCocque, Jonah, pp. 22, 217. For a similar reading of Jonah as "the typical Israelite," see T.E. Fretheim, The Message of Jonah: A Theological Commentary (Minneapolis, MN: Augsburg Publishing House, 1977), pp. 29-31, 43.

103) Marcus, Balaam to Jonah, p. 158.

104) See Berlin, “Rejoinder,” p. 227. 
about how a parody of the prophetic writings, which she claims were treated "with utmost seriousness throughout the rest of the Bible," came to be included among the prophetic books themselves. ${ }^{105}$ Because the parody itself would have treated the prophetic tradition with respect, there would be no need to assume, as Arnold Band does, that the book's parody was eclipsed as it was later given a "canonically acceptable interpretation." ${ }^{106}$ Instead, it may be precisely because the book's early readers recognized the way its parody upheld the prophetic ideal as a normative standard that they included it with the prophets.

\section{Reaffirming Parody: Job 7:17-18}

We come, finally, to the serious and respectful "reaffirming" parody. The book of Job is certainly not humorous, as even Whedbee, who argues that the book is a comedy in the generic sense, must agree. ${ }^{107}$ However, Dell claims the book's genre is best understood as parody. ${ }^{108}$ In so doing, she argues that "the definition of parody should not necessarily have to contain comedy." 109 This understanding of the book as a whole corresponds to the literary practice of many of its parts, as Dell demonstrates in her presentation of the widespread use of parody throughout the book. ${ }^{110}$

One of these intertextual connections, in which Job alludes to Ps. 8:5 in Job 7:17-18, has been widely referred to as a "bitter parody." 111 In the midst of a hymn praising God, the psalmist says:

\footnotetext{
105) Berlin, "Rejoinder," p. 227.

106) Band, "Swallowing Jonah," p. 184.

107) J.W. Whedbee, “The Comedy of Job,” Semeia 7 (1977), pp. 1-39.

108) Dell, Sceptical, pp. 109-57.

109) Dell, Sceptical, p. 152. See also pp. 148-53.

110) Dell, Sceptical, pp. 125-36.

111) Franz Delitzsch appears to be the first to note the parody in F. Delitzsch, Biblical Commentary on the Book of Job (trans. Francis Bolton; Clark's Foreign Theological Library, 10-11; Edinburgh: T. \& T. Clark, 1866), vol. 1, p. 124. The use of the phrase "bitter parody" to describe this intertextual connection goes back at least to T.K. Cheyne in 1887: T.K. Cheyne, Job and Solomon: or, The Wisdom of the Old Testament (New York: T. Whittaker, 1887), p. 88. The close parallel between the passages was observed as far back as John Chrysostom: J. Chrysostom, Kommentar zu Hiob (trans. U. Hagedorn and D. Hagedorn; Patristiche Texte und Studien, 35; Berlin: Walter De Gruyter, 1990), p. 86. According to Raymond Van Leeuwen, this
} 
What are human beings [מה־אנוֹשי] that you are mindful of them, mortals that you care [פקד] for them? (Ps. 8:5)

Job, however, twists the psalmist's words to express his anguish at God's domineering attention, as he laments:

What are human beings [מה־אנוש], that you make so much of them, that you set your mind on them,

visit פפקד] them every morning, test them every moment? (Job 7:17-18)

Job's antithetical evocation of the psalm is indicated both by the exact repetition of the opening words "What are human beings?" [מה־אנוש], the similar structure of his statement, and the use of the verb פקד to suggest God's testing in an ironically opposed sense to its use in the psalm, where it refers to divine care. ${ }^{112}$ It would make little sense for the psalmist to refer to this acerbic passage from Job in the midst of his hymn, since, as one early twentieth-century commentator put it, "[I]f the words were first used in Job's sense, would it be possible ever to take the acid out of them?" 113 Thus, the intertextual connection is best described as Job's parody of the psalm, as commentators widely recognize. ${ }^{114}$ Since Job alludes to the content of a particular psalm, this parody should be classified as specific and material.

description has "become proverbial" as demonstrated by its quotation by both Carol Newsom and David Clines without citation. See R.C. Van Leeuwen, "Psalm 8.5 and Job 7.17-18: A Mistaken Scholarly Commonplace?" in P.M. M. Daviau, et al. (eds.), The World of the Aramaeans I (JSOTSup, 324; Sheffield: Sheffield Academic Press, 2001), p. 206.

112) For a detailed description of the lexical affinity and thematic dissimilarity between the two texts see D.J.A. Clines, Job (WBC, 17-18A, B; Nashville: Thomas Nelson, 1989), vol. 1, pp. 192-93 and Fishbane, "Inner-Biblical Discourse," p. 87. Francis Andersen claims the lexical similarities between these two passages are too great to be a coincidence (F.I. Andersen, Job: An Introduction and Commentary [London: InterVarsity Press, 1976], p. 138).

113) J. Strahan, The Book of Job Interpreted (Edinburgh: T. \& T. Clark, 1913), p. 85.

114) For objections to this general consensus, see Van Leeuwen, "Psalm 8.5," pp. 20515; H. Schnieringer, Psalm 8: Text - Gestalt - Bedeutung (Ägypten und Altes Testament, 59; Wiesbaden: Harrassowitz, 2004), pp. 432-33. 
Considering the "bitterness" of Job's parody in Job 7, some label the chapter "Job's anti-psalm," 115 or his "doxology of sarcasm," 116 and argue that he not only overturns the question of Psalm 8 in a radically negative way but also sharply rejects the high image of humanity presented there. ${ }^{177}$ Following Dell, Tryggve Mettinger sees the parody as evidence that the book "emanates from a sceptical tradition." He even claims that in this skepticism "the proud proclamation of the glory of humanity that is the very point of Ps. 8.5-6 is left out," and that "Ps. 8.6 has no counterpart in the Job passage." 118

However, the context of the entire book draws this subversive interpretation of Job's parody into question. Christian Frevel refuses to assent to this negative assessment because he claims that the positive sense of Psalm 8, including Ps. 8:6, remains in the background of the allusion, as Job uses the parody to demand the glory and honor that it attributes to humanity for himself. ${ }^{119}$ For Frevel, the normative nature of Psalm 8 enables Job's parody to act not as an expression of sapien-

115) C.A. Newsom, "The Book of Job: Introduction, Commentary, and Reflections," The New Interpreter's Bible 4 (Nashville, TN: Abingdon Press, 1996), p. 395. Elsewhere, Newsom refers to this parody as an indicator of Job's "estranged relationship to inherited language and his challenge to its adequacy to express his experience or give knowledge of the world," C.A. Newsom, The Book of Job: A Contest of Moral Imaginations (Oxford: Oxford University Press, 2003), p. 131.

116) Balentine, “Divine Disclosure," p. 262.

117) H. Irsigler, "Die Frage nach dem Menschen in Psalm 8. Zu Bedeutung und Horizont eines kontroversen Menschenbildes im Alten Testament," in H. Irsigler (ed.), Vom Adamssohn zum Immanuel (ATAT, 58; St. Ottilien: Eos, 1997), p. 43. Similarly, L.G. Perdue, Wisdom and Cult: A Critical Analysis of the Views of Cult in the Wisdom Literatures of Israel and the Ancient Near East (SBLDS, 30; Missoula, MT: Scholars Press, 1976), pp. 130-31; J.G. Janzen, Job (Interpretation, Atlanta: John Knox Press, 1985), p. 82; Clines, Job, vol. 1, p. 193; H. Klein, "Zur Wirkungsgeschichte von Psalm 8," in R. Bartelmus, et al. (eds.), Konsequente Traditionsgeschichte. Festschrift für Klaus Baltzer zum 65. Gerburtstag (OBO; Göttingen: Vandenhoeck \& Ruprecht, 1993), p. 188; Balentine, “Divine Disclosure," p. 262

118) T.N.D. Mettinger, "Intertextuality: Allusion and Vertical Context Systems in Some Job Passages," in H.A. McKay and D.J.A. Clines (eds.), Of Prophets' Visions and the Wisdom of Sages (JSOTSup, 162; Sheffield: Journal for the Study of the Old Testament Press, 1993), p. 267.

119) Frevel, "Eine kleine Theologie," p. 261. 
tial skepticism, but as an argumentative device directed against God. ${ }^{120}$ According to Frevel, when Job later laments, "He has stripped my glory from me, and taken the crown from my head," (19:9) the words "glory" (כבוד) and "crown" (עטרה) allude to Ps. 8:6, where God is praised because he has "crowned" (root: עברוך) humanity with "glory (כבוד) and honor." 121 This continues Job's contrast of his experience with positive statements from the psalm. ${ }^{122}$ For Job to accuse God of tearing the crown from his head, he must assume that this is where it intrinsically belongs, and thus, though he parodies the psalm, a conviction of the dignity of humankind, which Psalm 8 declares, motivates his lament and accusation of God. ${ }^{123}$ Frevel argues that Psalm 8 remains the paradigm throughout the book that vindicates Job's lament against God, as Job himself is vindicated through his restoration while the friends and their low anthropology are rejected. ${ }^{124}$ Just as Householder believes the connotations of the English word "parody" have misled commentators into thinking Aristophanes was ridiculing Euripides, the lingering eighteenth-century understanding of the term may have misled commentators into believing Job is ridiculing Psalm 8. Just because Job is antithetically alluding to a psalm, he is not necessarily subverting its authority. In fact, the broader context of the dialogue suggests that his parody is intended to be a weapon to satirize God's behavior toward him.

\footnotetext{
120) Frevel, "Eine kleine Theologie," p. 262.

121) For others who recognize a possible allusion here, see Perdue, Wisdom and Cult, p. 174; L.A. Schökel and J.L. Sicre Díaz, Job: Comentario teológico y literario (Nueva Biblia Española, Madrid: Ediciones Cristiandad, 1983), p. 287; N.C. Habel, The Book of Job: A Commentary (OTL, Philadelphia: Westminster Press, 1985), p. 300; U. Neumann-Gorsolke, “"Mit Ehre und Hoheit hast Du ihn gekrönt" (Ps 8,6b): alttestamentliche Aspekte zum Thema Menschenwürde," JBTh 15 (2000), pp. 39-65 (55).

122) Frevel, "Eine kleine Theologie," p. 264.

123) Frevel, "Eine kleine Theologie," p. 266. Similarly, Neumann-Gorsolke, "Menschenwürde," p. 55.

124) Frevel, "Eine kleine Theologie," p. 269.
} 


\section{Conclusion}

We conclude with one final example that will put my paradigm to the test: the parallel between Isa. 2:4 and Joel 4:10. While prophesying a peace that will envelop the world's violence, Isaiah says:

... they shall beat their swords into plowshares, and their spears into pruning hooks ... (Isa. 2:4b)

\section{וכתתו חרבותם לאתים וחניתותיהם למזמרות}

Joel, however, envisions the nations in an eschatological battle, and commands them:

Beat your plowshares into swords, and your pruning hooks into spears ... (Joel 4:10ab)

\section{כתו אתיכם לחרבות ומזמרתיכם לרמחים}

With the exception of the change from imperfect to imperative and the use of a different word for spear (רמח instead of חנית), Joel uses Isaiah's exact words, but by reversing their order, he reverses their meaning. The parody, or better, parodies, in this intertext are complex, and the nearly exact repetition of the phrase from Isaiah in the midst of Micah's parallel of this extended prophecy does not help the situation, but we can leave that to the side. ${ }^{125}$ Joel's command to beat plowshares into swords reflects other "calls to battle" in the Hebrew Bible (e.g. Isa. 8:9-

\footnotetext{
125) For a discussion of the possible relationships between the Isaiah and Micah passages see F.I. Andersen and D.N. Freedman, Micah (AB, 24E; New York: Doubleday, 2000), pp. 413-25. They claim that how these two nearly identical passages came about "is a mystery not yet solved - perhaps forever insoluble" (414). Similarly, D.R. Hillers, A Commentary on the Book of the Prophet Micah (Hermeneia, Philadelphia: Fortress Press, 1984), p. 53. Because Micah's version is longer, and some of the changes appear to be attempts to smooth out Isaiah's version, Hans Walter Wolff and James Limburg believe Micah has adapted the passage from Isaiah. See H.W. Wolff, "Swords into Plowshares: Misuse of a Word of Prophecy?" trans. Gary Stansell, CurTM 12 (1985), pp. 133-47 (141); J. Limburg, "Swords to Plowshares: Text and Contexts," in vol. 1 of C.C. Broyles and C.A. Evans (eds.), Writing and Reading the Scroll of Isaiah: Studies of an Interpretive Tradition (VTSup, 70; Leiden: Brill, 1997), vol. 1, p. 285.
} 
10; 21:5; Jer. 46:3-4; 51:11), which Robert Bach claims preserve ancient summons to war. ${ }^{126}$ If this is the case, then Isaiah's promise of swords being turned into plowshares would itself be a rejecting (serious, subversive) parody of this proverbial saying, thereby giving his prophecy more rhetorical impact. ${ }^{127}$

That Joel is returning to the original proverb, as Bach claims, ${ }^{128}$ does not eliminate the parody of Isaiah in his statement. As Hugh Williamson remarks, "[T]he specifically ironic contrast with the Isaiah and Micah vision should not thereby be overlooked or downplayed." ${ }^{\prime 29}$ In fact, given Joel's proclivity for picking up phrases from earlier prophets, and the likely popularity of this passage in Isaiah given its repetition in Micah, it seems probable that, even if Joel's prophecy reasserts a traditional proverb, it does so with Isa. 2:4 (and possibly Mic. 4:3) in mind. ${ }^{130}$ Thus, Joel parodies Isaiah's parody of the traditional call to battle.

126) R. Bach, Die Aufforderung zum Kampf und zur Flucht im alttestamentlichen Prophetenspruch (WMANT, 9; Neukirchen: Neukirchener Verlag, 1962). Similar use of the trope of transforming agricultural tools into weapons in other ancient texts supports Bach's observation. See A. van Selms, "Isaiah 2:4: Parallels and Contrasts," OTWSA 22-23 (1979), pp. 230-39. He gives examples from Virgil's Georgics i. 506-8 (“Respect for the plough is gone; our lands, robbed of the tillers lie waste, and curved pruning hooks are forged into straight blades") and Ovid's Fasti i.697-700 ("Long time did wars engage mankind; the sword was handier than the share; the plough ox was ousted by the charger; hoes were idle, mattocks were turned into javelins, and helmet was made out of a heavy rake").

127) Limburg, "Swords," p. 288. Similarly, H.G.M. Williamson, Isaiah 1-27 (ICC, London: T \& T Clark, 2006), p. 186.

128) Bach, Aufforderung, p. 72 n. 1.

129) Williamson, Isaiah 1-27, p. 186 n. 74.

130) H.W. Wolff, A Commentary on the Books of the Prophets Joel and Amos (trans. W. Janzen, S.D. McBride, Jr., and C.A. Muenchow; Hermeneia; Philadelphia: Fortress Press, 1977), p. 80; Wolff, “Swords," p. 141. For extensive treatment of Joel's use of earlier texts, see J. Strazicich, Joel's Use of Scripture and the Scripture's Use of Joel: Appropriation and Resignification in Second Temple Judaism and Early Christianity (Biblical Interpretation Series, 82; Leiden: Brill, 2007). For a defense of an eighth-century dating of Isa. 2:2-4 in response to objections from Clements, Barth, and Sweeney, see B.D. Sommer, "Allusions and Illusions: The Unity of the Book of Isaiah in Light of Deutero-Isaiah's Use of Prophetic Tradition,” in R.F. Melugin and M.A. Sweeney 
Though Joel reverses Isaiah's phrase, his version does not necessarily contradict Isaiah's usage. Instead, just as he mockingly encourages the enemies of God's people to do, Joel may be taking an instrument of peace and twisting it into a weapon. By drawing on the earlier prophecy, Joel puts his prophecy in dialogue with it. ${ }^{131}$ John Strazicich claims Joel's purpose is to "de-establish" the ideology of peaceful pilgrimage of the Gentiles to Zion. ${ }^{132}$ However, if we see this as a "reaffirming" parody, Joel may instead intend to hold up this earlier text as the ideal, which the nations violate to their detriment. Thus, Joel's parody puts a choice before the nations. Isaiah had promised peace; Joel affirms that that peace will indeed come, whether the nations oppose it or not. As Hans Walter Wolff puts it, "The phrase 'plowshares into swords' makes a blunt mockery of the world powers, who think that by completely arming themselves with much effort they will have power and superiority over the people of God." 133 The parody mocks the world powers and not Isaiah's prophecy, and thus, as Wolff affirms, there is ultimately no opposition between the message of the two texts. ${ }^{134}$ Joel's version updates Isaiah's prophecy. ${ }^{135}$ The prophecy of peace is not "de-established," but the nations' experience of that peace is now made conditional. ${ }^{136}$ This understanding gives new significance to Joel's statement in v. 14 that the multitudes have come to the "valley of decision." Thus, while Isa $2: 4$, as a "rejecting" parody, asserts its authority over the

(eds.), New Visions of Isaiah (JSOTSup, 214; Sheffield: Sheffield Academic Press, 1996), pp. 163-64 n. 16.

131) Strazicich, Joel's Use of Scripture, p. 233.

132) Strazicich, Joel's Use of Scripture, p. 234.

133) Wolff, "Swords," p. 134. John Barton explains that the command to beat plowshares into swords could be directed toward either the Israelites or the nations. He, like Wolff, opts for the latter option (J. Barton, Joel and Obadiah: A Commentary (OTL, Louisville: Westminster John Knox Press, 2001), pp. 103-104.

134) "Once the context of the passage is correctly understood, we find not an opposition between Joel [4] and Isaiah 2, but instead in both texts the declaration of an end to the wars of the nations" (Wolff, "Swords," p. 135).

135) Sommer argues that Deutero-Isaiah's "reversals" of Jeremiah's prophecies have a similar effect (Sommer, A Prophet Reads Scripture, p. 41).

136) Strazicich does not differentiate between Isaiah's promise of peace and the Gentile's inclusion within it and so claims the prophecy as a whole is made conditional. See Strazicich, Joel's Use of Scripture, p. 234. 
traditional call to battle, Joel's "reaffirming” parody of Isaiah's prophecy appeals to that prophecy's authority to mock the militant nations.

As I hope the treatment of the biblical texts above has demonstrated, this new paradigm for parody can serve as a tool to help interpreters recognize parodies and then to determine the meanings of those texts. The vital hermeneutical question which this paradigm highlights is not whether a text is on the left (humorous) or right (serious) side of the table, but whether it is on the top, and the parody is asserting its authority over an earlier text, or on the bottom, and the precursor is being appealed to as an authority itself. In other words, whether, to use the imagery of Joel 4:10, the parody is being beaten into a sword targeting an earlier text, or the parodied text is being beaten into a spear aimed satirically at the situation depicted in the parody. Only a careful reading of the broader context will enable interpreters to decide. 